\title{
Approach to tap water safety analysis in terms of biostability
}

\author{
Barbara Tchórzewska-Cieślak ${ }^{1}$, Dorota Papciak $^{2}$, Katarzyna Pietrucha-Urbanik $^{1, *}$, and Andżelika Pietrzyk ${ }^{2}$ \\ ${ }^{1}$ Rzeszow University of Technology, Faculty of Civil, Environmental Engineering and Architecture, Department of Water Supply \\ and Sewerage Systems, Al. Powstancow Warszawy 6, 35-959 Rzeszow, Poland \\ ${ }^{2}$ University of Technology, Faculty of Civil, Environmental Engineering and Architecture; Department of Water Purification and \\ Protection, Al. Powstancow Warszawy 6, 35-959 Rzeszow, Poland
}

\begin{abstract}
The subject of the work is the analysis and assessment of the risk of biological instability of water. The lack of water stability causes the increased susceptibility of the distribution system to secondary microbial contamination of water and constitutes a hazard for consumers' health. The risk is expressed as the loss of water supply safety and distinguishes a failure of not meeting certain water quality parameters that can influence physico-chemical parameters and the bacteriological quality of the water supplied to the consumers. In the paper the method of analysing and evaluating the risk of loss of biostability of tap water is presented. The presented analysis was performed on the basis of the operating data from the water treatment plant.
\end{abstract}

\section{Introduction}

The primary and basic subject to which the concept of water safety concerns is the consumer. A measure of safety in relation to water consumers is risk, defined as the probability of undesirable event occurrence, whose consequence may be a real threat to the lives or health of water consumers [1-4].

When analysing the functioning of the water distribution subsystem (WDS) in terms of the protection of water consumers mainly the resistance of system to various types of undesirable events, that may occur in the subsystem is taken into account $[5,6]$. The consequence of these events may be break in water supply or the so called secondary water pollution in the water supply network. Hydraulic conditions in the WDS influence changes in the physicochemical and bacteriological water composition. The important problem that arises in many urban water supply systems is also the significant pipes oversizing which results in a decrease in the flow velocity of water and, consequently, in unfavourable flow conditions that cause deterioration of water quality in the water supply network.

The main objective of the paper is to present a methodology for analysing and assessing the risk of biological instability in terms of the water consumers safety.

\section{Research methodology}

\subsection{Water biological stability}

Biofilm is a group of microorganisms that are linked by trophic dependence from autotrophic and heterotrophic bacteria and fungal toxins and their parallel developing consumers, such as flagellates, ciliates, and creepers [7$12]$.

Bio-stable water is considered to be non-microbial and does not sustain the growth of microorganisms in the water supply network.

The epidemiological risk caused by the presence of biological membrane in the water supply network is related both to the quality and type of water taken by the water treatment plants and to the efficiency of treatment and disinfection processes [13-17].

Based on the conducted studies, it was found that the intensity of microorganisms growth in the water supply network is mainly determined by the presence of organic compounds, in particular biodegradable dissolved organic carbon (BDOC) and assimilable organic carbon (AOC).

The values of these parameters indicate the content of nutrients that can be easily assimilated by water-borne microorganisms. The AOC concentration in the water entering the network is usually $0.1-9 \%$ of dissolved organic carbon (DOC) and about 15-25\% of biodegradable dissolved organic carbon (BDOC) [7] .

The conventional water purification system based on coagulation, sedimentation, filtration and disinfection eliminates the AOC fraction in less than $30 \%$ and total organic carbon (TOC) in 22\%, while the system extended with an additional biofiltration by activated carbon deposit removes these fractions up to 60 and even $74 \%$ [18-25].

For the risk analysis and assessment, the following threshold values for the biological stability parameters of water were adopted: $\mathrm{BDOC}<0.25 \mathrm{gC} / \mathrm{m}^{3}, \Sigma \mathrm{N}_{\text {inorganic }}$ $<0.2 \mathrm{gN} / \mathrm{m}^{3}, \mathrm{PO}_{4}{ }^{3-}<0.03 \mathrm{gPO}_{4}{ }^{3-} / \mathrm{m}^{3}$, on the basis of [7].

* Corresponding author: kpiet@prz.edu.pl 


\subsection{Method of risk analysis and assessment of lack of water biological stability}

The value of the risk of biological instability of water in the water supply network describes the so-called risk function $\mathrm{f}(\mathrm{r})$, defined as the expected value of losses under certain system operating conditions that influence the system's vulnerability (resistance) to threat [3, 2630].

In the risk analysis, the priority is to identify potential threats. Risk assessment is a comparison of the obtained risk value with the assumed criteria values.

For the analysis of the risk of loss of water biological stability, the following risk definition was adopted:

$$
r=E\left[C \geq C_{g r}=f\left(S_{1}, S_{2}, S_{3}\right)\right]
$$

where $E\left(C \geq C_{g r}\right)$ is the expected value of losses $\mathrm{C}$ greater than the accepted limit losses $C_{g r}$. where $S_{l}$ is the criterion corresponding to the content of BDOC, $\mathrm{gC} / \mathrm{m}^{3}$, $\mathrm{S}_{2}$ is the criterion corresponding to inorganic content $\sum \mathrm{N}_{\text {inorganic }}, \mathrm{gN} / \mathrm{m}^{3}, S_{3}$ is the criterion corresponding to $\mathrm{PO}_{4}^{3-}, \mathrm{gPO}_{4}^{3-} / \mathrm{m}^{3}$.

The limit values were proposed for the probability of exceeding the parameters BDOC, $\sum \mathrm{N}_{\text {inorganic }}$ and $\mathrm{PO}_{4}{ }^{3-}$ based on the criteria contained in the work [7].

Assuming that $P_{S}$ is the probability of not exceeding the water quality parameters (BDOC, $\sum \mathrm{N}_{\text {inorganic }}$ and $\mathrm{PO}_{4}{ }^{3-}$ ), $P_{i}$ is the probability of not exceeding the water quality parameters (BDOC, $\sum \mathrm{N}_{\text {inorganic }}$ and $\mathrm{PO}_{4}{ }^{3-}$ ) in a given water sample, $P_{p}$ is the probability of exceeding the water quality parameters (BDOC, $\sum \mathrm{N}_{\text {inorganic }}$ and $\mathrm{PO}_{4}{ }^{3-}$ ) and $P_{p i}$ is the probability of exceeding the water quality parameters (BDOC, $\Sigma \mathrm{N}_{\text {inorganic }}$ and $\mathrm{PO}_{4}{ }^{3-}$ ) in a given water sample.

$$
\begin{gathered}
P_{S}=\sum_{i \in E+} P_{i} \\
P_{i}=\prod_{j=1}^{M} P_{i 0} \cdot\left(1-P_{i 0}\right) \\
P_{S}=\sum_{i \in E_{+}} P_{i}
\end{gathered}
$$

The following criteria for the probability of exceeding BDOC, $\Sigma \mathrm{N}_{\text {inorganic }}$ and $\mathrm{PO}_{4}{ }^{3-}$ parameters, based on the formulas 2-4 and the work [7]:

- Tolerable risk $\left(R_{T}\right) \rightarrow C_{g r}=f\left(S_{1}, S_{2}, S_{3}\right)=\left(S_{1}=\mathrm{BDOC}\right.$ $\left.<0.25 \mathrm{gC} / \mathrm{m}^{3}\right) \wedge\left(S_{2}=\sum \mathrm{N}_{\text {inorganic }}<0.2 \mathrm{gN} / \mathrm{m}^{3}\right) \wedge\left(S_{3}=\right.$ $\left.\mathrm{PO}_{4}{ }^{3-}<0.03 \mathrm{gPO}_{4}{ }^{3-} / \mathrm{m}^{3}\right)$

- Controlled risk $\left(R_{C I}\right) \rightarrow C_{g r}=f\left(S_{1}, S_{2}, S_{3}\right)=\left(S_{1}=\right.$ BDOC $\left.<0.25 \mathrm{gC} / \mathrm{m}^{3}\right) \wedge\left(S_{2}=\sum \mathrm{N}_{\text {inorganic }}<0.2 \mathrm{gN} / \mathrm{m}^{3}\right) \wedge$ $\left(S_{3}=\mathrm{PO}_{4}{ }^{3-} \geq 0.03 \mathrm{gPO}_{4}{ }^{3-} / \mathrm{m}^{3}\right)$

- Controlled risk $\left(R_{C I I}\right) \rightarrow C_{g r}=f\left(S_{1}, S_{2}, S_{3}\right)=\left(S_{1}=\right.$ BDOC $\left.<0.25 \mathrm{gC} / \mathrm{m}^{3}\right) \wedge\left(S_{2}=\sum \mathrm{N}_{\text {inorganic }} \geq 0,2 \mathrm{gN} / \mathrm{m}^{3}\right) \wedge$ $\left(S_{3}=\mathrm{PO}_{4}{ }^{3-}<0.03 \mathrm{gPO}_{4}{ }^{3-} / \mathrm{m}^{3}\right)$

- Controlled risk $\left(R_{C I I I}\right) \rightarrow C_{g r}=f\left(S_{1}, S_{2}, S_{3}\right)=\left(S_{1}=\right.$ BDOC $\left.\left.\geq 0.25 \mathrm{gC} / \mathrm{m}^{3}\right) \wedge S_{2}=\sum \mathrm{N}_{\text {inorganic }}<0.2 \mathrm{gN} / \mathrm{m}^{3}\right) \wedge$ $\left(S_{3}=\mathrm{PO}_{4}{ }^{3-}<0.03 \mathrm{gPO}_{4}{ }^{3-} / \mathrm{m}^{3}\right.$

- Controlled risk $\left(R_{C I V}\right) \rightarrow C_{g r}=f\left(S_{1}, S_{2}, S_{3}\right)=\left(S_{1}=\right.$
BDOC $\geq 0.25 \mathrm{gC} / \mathrm{m}^{3} \wedge S_{2}=\sum \mathrm{N}_{\text {inorganic }} \geq 0.2 \mathrm{gN} / \mathrm{m}^{3} \wedge S_{3}$ $=\mathrm{PO}_{4}{ }^{3-}<0.03 \mathrm{gPO}_{4}{ }^{3-} / \mathrm{m}^{3}$

- Controlled risk $\left(R_{C V}\right) \rightarrow C_{g r}=f\left(S_{1}, S_{2}, S_{3}\right)=\left(S_{1}=\right.$ $\left.\mathrm{BDOC} \geq 0.25 \mathrm{gC} / \mathrm{m}^{3}\right) \wedge\left(S_{2}=\sum \mathrm{N}_{\text {inorganic }}<0.2 \mathrm{gN} / \mathrm{m}^{3}\right) \wedge$ $\left(S_{3}=\mathrm{PO}_{4}{ }^{3-} \geq 0.03 \mathrm{gPO}_{4}{ }^{3-} / \mathrm{m}^{3}\right)$

- Controlled risk $\left(R_{C V I}\right) \rightarrow C_{g r}=f\left(S_{1}, S_{2}, S_{3}\right)=\left(S_{1}=\right.$ BDOC $\left.<0.25 \mathrm{gC} / \mathrm{m}^{3}\right) \wedge\left(S_{2}=\sum \mathrm{N}_{\text {inorganic }} \geq 0.2 \mathrm{gN} / \mathrm{m}^{3}\right) \wedge$ $\left(S_{3}=\mathrm{PO}_{4}{ }^{3-} \geq 0.03 \mathrm{gPO}_{4}{ }^{3-} / \mathrm{m}^{3}\right)$

- Unacceptable risk $\left(R_{\text {una }}\right) \rightarrow C_{g r}=f\left(S_{1}, S_{2}, S_{3}\right)=\left(S_{1}=\right.$ BDOC $\left.\geq 0.25 \mathrm{gC} / \mathrm{m}^{3}\right) \wedge\left(S_{2}=\sum \mathrm{N}_{\text {inorganic }} \geq 0.2 \mathrm{gN} / \mathrm{m}^{3}\right) \wedge$ $\left(S_{3}=\mathrm{PO}_{4}{ }^{3-} \geq 0.03 \mathrm{gPO}_{4}{ }^{3-} / \mathrm{m}^{3}\right)$

In Table 1 the values for the probability of exceeding

\begin{tabular}{|c|c|c|c|c|}
\hline Criteria & PBDOC & $\mathbf{P N}_{\text {inorganic }}$ & $\mathrm{PPO}_{4}{ }^{3-}$ & $\mathrm{E}(\mathrm{C})$ \\
\hline$R_{T}$ & 0.417 & 0.841 & 0.99 & 0.34719 \\
\hline$R_{C I}$ & 0.417 & 0.841 & 0.01 & 0.00350 \\
\hline$R_{C I I}$ & 0.417 & 0.159 & 0.99 & 0.06564 \\
\hline$R_{C I I I}$ & 0.583 & 0.841 & 0.99 & 0.48540 \\
\hline \multicolumn{4}{|r|}{$\sum R_{C I-I I I}$} & 0.55454 \\
\hline$R_{C I V}$ & 0.583 & 0.159 & 0.99 & 0.09177 \\
\hline$R_{C V}$ & 0.583 & 0.841 & 0.01 & 0.00490 \\
\hline$R_{C V I}$ & 0.417 & 0.159 & 0.01 & 0.00066 \\
\hline \multicolumn{4}{|r|}{$\sum R_{C I V-V I}$} & 0.09734 \\
\hline$R_{\text {una }}$ & 0.583 & 0.159 & 0.01 & 0.00093 \\
\hline
\end{tabular}
BDOC, $\Sigma \mathrm{N}_{\text {inorganic }}$ and $\mathrm{PO}_{4}{ }^{3-}$ parameters were presented.

Table 1. The values for the probability of exceeding BDOC, $\sum \mathrm{N}_{\text {inorganic }}$ and $\mathrm{PO}_{4}{ }^{3-}$ parameters.

In addition, the controlled risk should be adopted if one of the six criteria is met. For risk analysis, the following values of limit losses $E\left(C<C_{g r}\right)$, related to maintain the biological stability of tap water, were assumed:

- tolerable risk $\left(R_{T}\right)$ - water is biologically stable with the criteria presented in Table 1 . The expected value $E\left(C<C_{g r}\right)$ is expressed by the probability $P_{R T}=$ 0.34719 ,

- controlled risk $\left(R_{C}\right)$ - there are premises for maintaining the biological stability of water if the parameters shown in Table 1 are maintained. The expected value $E\left(C<C_{g r}\right)$ with the probability for conditions I-III is $P_{R C I-I I I}=0.55454$, for the rest conditions $P_{R C I V-V I}=0.09734$,

- unacceptable risk $\left(R_{\text {una }}\right)$ - water is biologically unstable at the parameters shown in Table 1 . The expected value $\mathrm{E}(\mathrm{C}<\mathrm{Cgr})$ with the probability $P_{\text {una }}=0.00093$.

The parameters defining the tolerable risk area indicate that the parameters of water provide the required biological stability in the water supply network (acceptable safety level $\left(\mathrm{SL}_{\mathrm{T}}\right)$ ), whereas the controlled risk means that the water quality parameters indicate the possibility of changes in the chemical stability of water in the water supply network (safety level which requires control and reduction of $\left.\left(\mathrm{SL}_{\mathrm{C}}\right)\right)$. The unacceptable risk means the occurrence of such water quality parameters that cause biological instability of water in the water 
supply network, which may result in the secondary contamination (unacceptable safety level ( $\left.\mathrm{SL}_{\mathrm{UNA}}\right)$ ).

\section{Analysis of the selected water distribution system}

\subsection{Characteristics of the research object}

The analysis of the underground water treatment system is performed for the city of 80 thousand inhabitants. Water devices for the water intake are SI pumps consisting of 5 drilling wells $\left(Q_{\text {emax }} 183 \mathrm{~m}^{3} / \mathrm{h}\right.$ ) and SII consisting of 22 drilling wells $\left(Q_{\text {emax }}=715 \mathrm{~m}^{3} / \mathrm{h}\right)$. The designed maximum capacity of the water treatment plant (WTP) is $715 \mathrm{~m}^{3} / \mathrm{h}$. The annual average, for example in $2012 / 2013$, was about $265 \mathrm{~m}^{3} / \mathrm{h}$.

The treated water is discharged from the clean water tank to the two water mains through 3 pumps. Two of them have a capacity of $440 \mathrm{~m}^{3} / \mathrm{h}$ and the third one the capacity of $280 \mathrm{~m}^{3} / \mathrm{h}$. Their lifting capacity is $58 \mathrm{~m}$. The city's water supply network consists of the $16.8 \mathrm{~km}$ main network, $176.6 \mathrm{~km}$ of the distributional network. The household connections network consists of 3958 connections and has length of $98.40 \mathrm{~km}$. Approximately $42.70 \%$ of the entire water supply network is made of pipes less than 20 years old but more than 11 years old. $90.2 \mathrm{~km}$ of the network is made of materials less than 10 years old.

The intake water does not meet sanitary requirements in terms of turbidity, colour, permanganate index, ammonium, iron and manganese. The physicochemical composition of the intake water indicates that there may be difficulties in its treatment. The physical and chemical parameters of the intake water are as follows: turbidity 8-14 NTU, colour Hazen 40-100, permanganate index 11.0-18.1 $\mathrm{g} \mathrm{O}_{2} / \mathrm{m}^{3}$, ammonium ion 1.2-1.98 $\mathrm{g}$ $\mathrm{NH}_{4}{ }^{+} / \mathrm{m}^{3}$, iron 14.0-44.0 g Fe $/ \mathrm{m}^{3}$, manganese $0.74-2.58 \mathrm{~g}$ $\mathrm{Mn} / \mathrm{m}^{3}$, TOC $14-20 \mathrm{~g} \mathrm{C} / \mathrm{m}^{3}$, total hardness 4.0-9.4 val $/ \mathrm{m}^{3}$, sulfates $60-240 \mathrm{~g} \mathrm{SO}_{4}{ }^{2-} / \mathrm{m}^{3}$. The intake water is directed to the collection well (stop time 2-4 hours, depending on the current water production). Then the water is directed to the oxygenation cascade. Just beneath the cascade lies the dosage of chemical oxidant potassium permanganate and coagulant PAX-18. The next step in water treatment is vertical coagulatory and sedimentation chambers with a contact time of 6-8 hours. To the water after the chambers, which is directed to the horizontal settlers, calcium milk is dosed to raise the $\mathrm{pH}$. The settling time in the settlers is several hours. The next step is the filtration of water in the filters at a rate of $1.5-3 \mathrm{~m} / \mathrm{h}$ and the final step - disinfection with sodium hypochlorite.

\subsection{Physicochemical parameters determination of the treated water}

Samples of water were taken twice a month from November 2015 to November 2016. The treated water was taken from the clean water tank prior to the final disinfection process. The modified Kaplan and Newbold method was used to determining the BDOC content by using for this purpose colonized by autochthonous bacteria bioreactor with granular activated carbon.

The physicochemical parameters were determined according to the applicable research procedures: ammonium nitrogen - direct nesserization method according to PN-C-04576-4:1994P, nitric nitrogen (III) colorimetric method with 4-diazobenzenesulfonic acid according to PN-EN26777:1999), nitrate nitrogen (V) colorimetric method with sodium salicylate according to PN/C-04576.08, phosphates - spectrometric method with ammonium molybdate according to PN-EN ISO 6878, TOC - TOC analyzer Sievers 5310 C/PN - EN 1484:1999, BDOC - the modified Kaplan and Newbold method [25].

\subsection{Risk analysis and assessment}

The existing water treatment station very effectively removes iron and manganese. In the treated water there are traces of these impurities. On the other hand, the colour parameter is maintained at 10-15 Hazen, with an acceptable Hazen value of 15 . In the discussed example the colour was affected by organic substances - the content of TOC in the treated water was $7-12 \mathrm{~g} \mathrm{C} / \mathrm{m}^{3}$, exceeding the value recommended by the WHO - $5 \mathrm{~g} \mathrm{C} / \mathrm{m}^{3}$. Other parameters of the treated water are as follows: BDOC $2.27-11.20 \mathrm{~g} / \mathrm{m}^{3}, \Sigma \mathrm{N}_{\text {inorganic }} 0.16$ $1.20 \mathrm{~g} / \mathrm{m}^{3}$ and $\mathrm{PO}_{4}{ }^{3-} 0-0.007 \mathrm{~g} / \mathrm{m}^{3}$. The detailed analysis of BDOC, $\mathrm{N}_{\text {inorganic }}$ and $\mathrm{PO}_{4}{ }^{3-}$ parameters was performed to analyse the risk of lack of biological stability.

Fig. 1 shows the parameters of the treated water and the safety criteria established in Table 1.

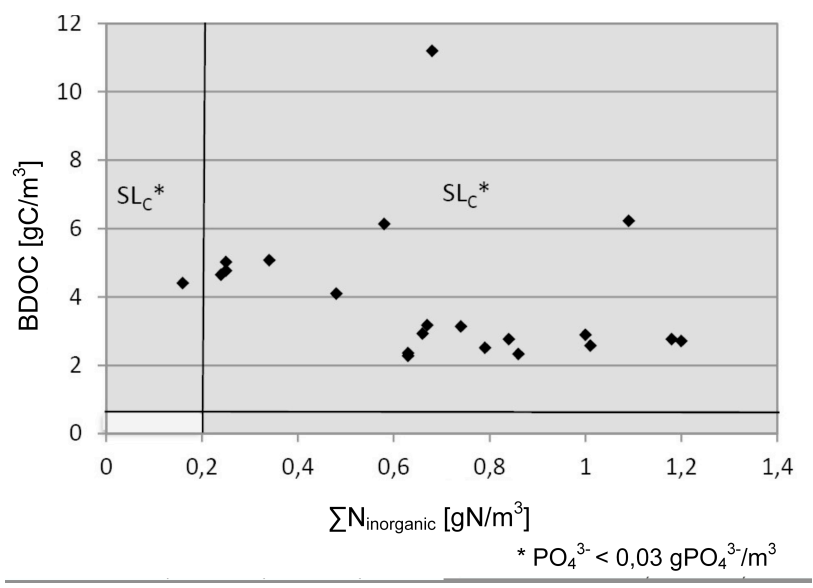

Fig. 1. Criteria for determining the individual safety levels taking into account the parameters of the treated water.

All tested samples are in the range of controlled risk $\left(R_{C}\right)$. Of the 22 tested water samples 21 corresponds to variant IV of controlled risk $\left(R_{C}\right)$ :

IV. $C_{g r}=f\left(S_{1}, S_{2}, S_{3}\right)=\left(S_{1}=\mathrm{BDOC} \geq 0.25 \mathrm{gC} / \mathrm{m}^{3}\right) \wedge$ $\left(S_{2}=\sum \mathrm{N}_{\text {inorganic }} \geq 0.2 \mathrm{gN} / \mathrm{m}^{3}\right) \wedge\left(S_{3}=\mathrm{PO}_{4}{ }^{3-}\right.$ $<0.03 \mathrm{gPO}_{4}{ }^{3-} / \mathrm{m}^{3}$ )

One sample of water corresponds to variant III of 
controlled risk $\left(R_{C}\right)$ :III. $C_{g r}=f\left(S_{1}, S_{2}, S_{3}\right)=\left(S_{I}=\right.$ BDOC $\left.\geq 0.25 \mathrm{gC} / \mathrm{m}^{3}\right) \wedge\left(S_{2}=\sum \mathrm{N}_{\text {inorganic }}<0.2 \mathrm{gN} / \mathrm{m}^{3}\right) \wedge\left(S_{3}=\right.$ $\left.\mathrm{PO}_{4}{ }^{3-}<0.03 \mathrm{gPO}_{4}{ }^{3-} / \mathrm{m}^{3}\right)$

The controlled risk level $\left(R_{C}\right)$ means that the nature of the water samples determined by BDOC, $\Sigma \mathrm{N}_{\text {inorganic }}$ and $\mathrm{PO}_{4}{ }^{3-}$ corresponds to a safety level that requires control and reduction $\left(\mathrm{SL}_{\mathrm{C}}\right)$.

\section{Conclusions}

Conventional water purification processes i.e. coagulation, sedimentation, filtration and disinfection do not provide effective elimination of biogenic substances and, in particular, BDOC and inorganic nitrogen. Because of the insufficient degree of nutrient removal it is necessary to include to conventional water treatment systems the additional unit processes or to optimize the existing ones.

For the considered technological variant the treated water corresponds to a safety level which requires control and reduction $\left(\mathrm{SL}_{\mathrm{C}}\right)$ to a level where there are the premises of maintaining the biological water stability. In case of the tolerable risk, the further monitoring and the maintenance of the current level of drinking water quality are recommended.

The controlled risk indicates the need for correction in the water treatment process. In case of receiving the unacceptable level of risk, it is recommended to supplement the technological process, e.g. by using the biofiltration process.

\section{References}

1. I. Zimoch, Ochr. Srod. 31 (2009)

2. I. Zimoch, E. Lobos, T. Zaba, Conf. Proc. Safety and Reliability: Methodology and Applications. (Boca Raton: CRC Press-Taylor \& Francis Group, 2015)

3. M-C. Bessner, V. Gauthier, B. Barbeau, R. Millette, R. Chapleau, M. Prevost, J. Am. Water Works Assoc. 93 (2001)

4. J. Rak, Environ. Prot. Eng. 29 (2003)

5. B. Tchorzewska-Cieslak, J. Rak, Congress Proc. of Environmental Engineering, (Lublin, Poland, 2010)

6. J. Królikowska, Rocz. Ochr. Sr. 13 (2011)

7. M. Wolska, Usuwanie substancji biogennych $w$ technologii oczyszczania wody przeznaczonej do spożycia przez ludzi (Oficyna Wydawnicza Politechniki Wrocławskiej, Wrocław, 2015)

8. M.J. Lethola, I.T. Miettinen, T. Lampola, A. Hirvonen, T. Vartiainen, P. J. Martikainen, Water Res. 39 (2005)

9. B. Toczyłowska, Tech. Wody 45 (2016)

10. V. Ondrejka Harbulakova, A. Estokova, M. Kovalcikova, Environ. 4 (2017).

11. M. Łebkowska, E. Pajor, A. Rutkowska-Narożniak, M. Kwietniewski, J. Wąsowski, D. Kowalski, Ochr. Srod. 33 (2011)
12. B. Kołwzan, Ochr. Srod. 33 (2011)

13. I. Biedroń, A. Trusz-Zdybek, T. Traczewska, Instal 5 (2013)

14. J. Wingender, H.C. Flemming, Int. J. Hyg. Environ. Health 214 (2011)

15. T.M. Traczewska, M. Sitarska, Ochr. przed korozją 55 (2012)

16. V. Ondrejka Harbuláková, A. Eštoková, N. Števulová, Nadežda, A. Luptaková, Int. J. Renew. Energy Environ. Eng. 5 (2014)

17. T.M. Traczewska, M. Sitarska, I. Biedroń, Ekologiczne $i$ techniczne aspekty powstawania biofilmu $w$ wodzie (Oficyna Wydawnicza Politechniki Wrocławskiej, Wroclaw, 2014)

18. M. Świderska-Bróż. Ochr. Srod. 34 (2012)

19. M. Kabsch-Korbutowicz, Zaawansowane metody usuwania naturalnych substancji organicznych $z$ wody. (Komitet Inżynierii Środowiska PAN, Lublin, 2012)

20. A. Pietrzyk, D. Papciak, JCEEA. 63 (2016)

21. D. Papciak, J. Kaleta, A. Puszkarewicz, B. Tchórzewska-Cieślak, J. Ecol. Eng. 17 (2016)

22. M.K. Ramseier, A. Peter, J. Traber, U. Von Gunten, Water Res. 45 (2011)

23. P. Thayanukul, F. Kurisu, I. Kasuga, H. Furumai, Water Res. 47 (2013)

24. Ch. J. Volk, M. W. LeChevallier, J. Am. Water Works Assoc. 92 (2000)

25. L.A. Kaplan, J. D. Newbold, Water Res. 12 (1995)

26. J. Rak, B. Tchórzewska-Cieślak, J. Konbin. 3 (2010)

27. K. Boryczko, B. Tchorzewska-Cieslak, Conf. Proc. on Environmental Engineering, (Lublin, Poland, 2012)

28. J. R. Rak, B. Kucharski, Environ. Prot. Eng. 35, (2009)

29. I. Zimoch, Ochr. Sr. 34 (2012)

30. I. Zimoch, E. Łobos, Environ. Prot. Eng. 38 (2012) 